\title{
APPLICATION OF XBEACH TO MODEL STORM RESPONSE ON A MACROTIDAL GRAVEL BARRIER
}

\begin{abstract}
Amaia Ruiz de Alegria-Arzaburu', Jon J. Williams ${ }^{1}$ and Gerhard Masselink ${ }^{1}$
The process-based XBeach numerical model has been used to simulate storm-induced morphological response on a macrotidal gravel barrier located in southwest UK. Using well-established parameterisation to define all relevant hydrodynamic, groundwater and sediment processes, the model was applied in 1D mode to simulate observed storminduced beach profile responses. Investigations showed that the morphological response of the beach was best modelled using a total drag coefficient, $\mathrm{C}_{\mathrm{D}}$ of 0.007 , and a hydraulic conductivity, $\mathrm{K}$, of $0.05 \mathrm{~ms}^{-1}$. Results obtained from simulations with and without beach groundwater highlighted the need to account for groundwater effects when modelling morphological changes on gravel beaches. The model has been found unable of reproducing the formation of a berm, thus, beach recovery conditions cannot be modelled. This is mainly attributed to the fact that XBeach models long waves rather than individual waves, and thus it cannot simulate individual swash events that contribute to onshore sediment transport and berm accretion. However, the model is shown to provide good estimates of post-storm gravel beach/barrier profiles, and to define the threshold for overwash occurrence. Both attributes have utility in a range of practical coastal engineering and management applications.
\end{abstract}

Keywords: XBeach; gravel barrier; modelling; storm response; barrier overwash; morphodynamics.

\section{INTRODUCTION}

Gravel beaches are considered to be efficient natural sea defences (Bradbury and Powell 1992; VanWellen et al. 2000; Bradbury 2000; Mason and Coates 2001), and coarse grained sediment is being used increasingly to replenish eroded beaches as a soft engineering measure, often in combination with structures (e.g., Riddell and Young 1992; Van Wellen et al. 2000). However gravel beach environments are sensitive to storm-induced coastal retreat, and currently most UK gravel beach/barrier systems are experiencing erosion (Chadwick et al. 2005; Pye and Blott 2009). The increase of the hydraulic forcing by storm surge and waves during storms often induces the process of barrier overwash, which causes barrier crest erosion, and increases the vulnerability of the barrier to further erode. Therefore, there is a practical need to develop tools for predicting the response of gravel beaches/barriers to storms.

Despite a wide recognition that longshore sediment transport and sediment supply play a crucial role in gravel beach dynamics, overall, the processes that cause erosion of gravel beaches are poorly understood. In the past two decades several field experiments have been undertaken on gravel beaches with the aim of collecting concurrent wave measurements and morphological data to enable the calibration of sediment transport equations. Most of these experiments have observed sediment transport processes using tracers, traps or profile/shoreline change (e.g., Nicholls and Wright 1991; Chadwick 1989; Van Wellen et al. 2000).

Owing to a paucity of appropriate sediment transport formula for coarse sediment, predictions of gravel beach response to hydrodynamic forcing frequently are based on sediment transport models developed for sandy beaches, leading to inaccuracies. Further, the transport formulae that are used require the input of hydrodynamic parameters that are difficult to measure on gravel beaches, as frequently, instruments are damaged or lost in the highly energetic nearshore conditions. This difficulty has been partially overcome through laboratory experiments (Powell 1990; Bradbury and Powell 1992; Bradbury 2000; Lopez de San Roman-Blanco et al. 2006; Obhrai et al. 2008; Williams et al. 2009), which aim to gain an understanding of the physical processes, and allow the development of the first numerical models for gravel beaches. In spite of progress in this area some scaling problems remain unresolved.

Numerical models attempt to describe the inshore hydrodynamics and sediment transport in time and space, and are based on an understanding of the underlying physical processes. However, limited understanding of the physical processes on gravel beaches has restricted the development of processbased numerical models. At present, the few existing cross-shore (i.e., Clarke and Damgaard 2002; Pedrozo-Acuña et al. 2006) and longshore (Brampton and Motyka 1984; Chadwick 1989; Riddell and Young 1992; Chadwick et al. 2005) models are not yet fully capable of predicting the morphological response of gravel beaches hydrodynamic forcing. Ideally a transport model should integrate both cross-shore and alongshore processes from outside the surf zone up to the runup limit and include the complexities of wave/current/sediment interactions (Mason and Coates 2001). However, although significant progress has been made in modelling the complexities of beach hydrodynamics, sediment

\footnotetext{
${ }^{1}$ School of Marine Science and Engineering, University of Plymouth, Drake Circus, Plymouth, PL4 8AA, UK
} 
transport equations for gravel are based upon limited datasets (e.g., Van der Meer 1988; Chadwick 1989; Van Wellen et al. 2000; Soulsby and Damgaard 2005; Van Rijn 2007), and are not well-tested in beach environments.

At present, many morphological models aim to reproduce the main physical processes acting upon beaches under different wave forcing conditions, but most of these models contain computationally expensive routines that limit their practical application. XBeach is an open-source process-based numerical model that has been developed to assess the natural response of sandy coasts during timevarying storm and hurricane events (Roelvink et al. 2009). The model has been extensively validated for sandy coastlines with series of analytical, laboratory and field test cases (Van Dongeren et al. 2009; McCall et al. 2010; Lindemer et al. 2010), and offers the required two-dimensionality to study storm impacts of up to a few days of duration, and on coastal regions of alongshore and cross-shore lengths of up to $12 \mathrm{~km}$ and $3 \mathrm{~km}$, respectively. The present study is the first application of XBeach to simulate storm response and beach recovery on a macrotidal gravel beach/barrier system.

\section{FIELD SITE}

Slapton Sands is a macrotidal gravel barrier located in Start Bay, southwest England (Fig. 1). The barrier faces the English Channel from the east, and is approximately $4.5 \mathrm{~km}$ long, $80-120 \mathrm{~m}$ wide and has a crest elevation of 6-8 m above Ordnance Datum Newlyn (ODN, approximately $0.2 \mathrm{~m}$ above mean sea level in the UK). The barrier is devoid of coastal structures, it is aligned in a north-south orientation, and both the height and width of the barrier increase progressively in a northward direction. The southern half of the barrier encloses a freshwater lagoon, fed by three local streams, and which usually maintains a higher water table than the spring high tide level. The gravel-size sediment comprises mainly flint, chert and quartz, the mean sediment size is approximately $6 \mathrm{~mm}$, and beach slopes are typically $\tan \beta=0.1-0.2$. With the exception of some localised cliff erosion, which mainly produces easily erodible fragments of shale, Start Bay as a whole can be considered a closed sedimentary cell.

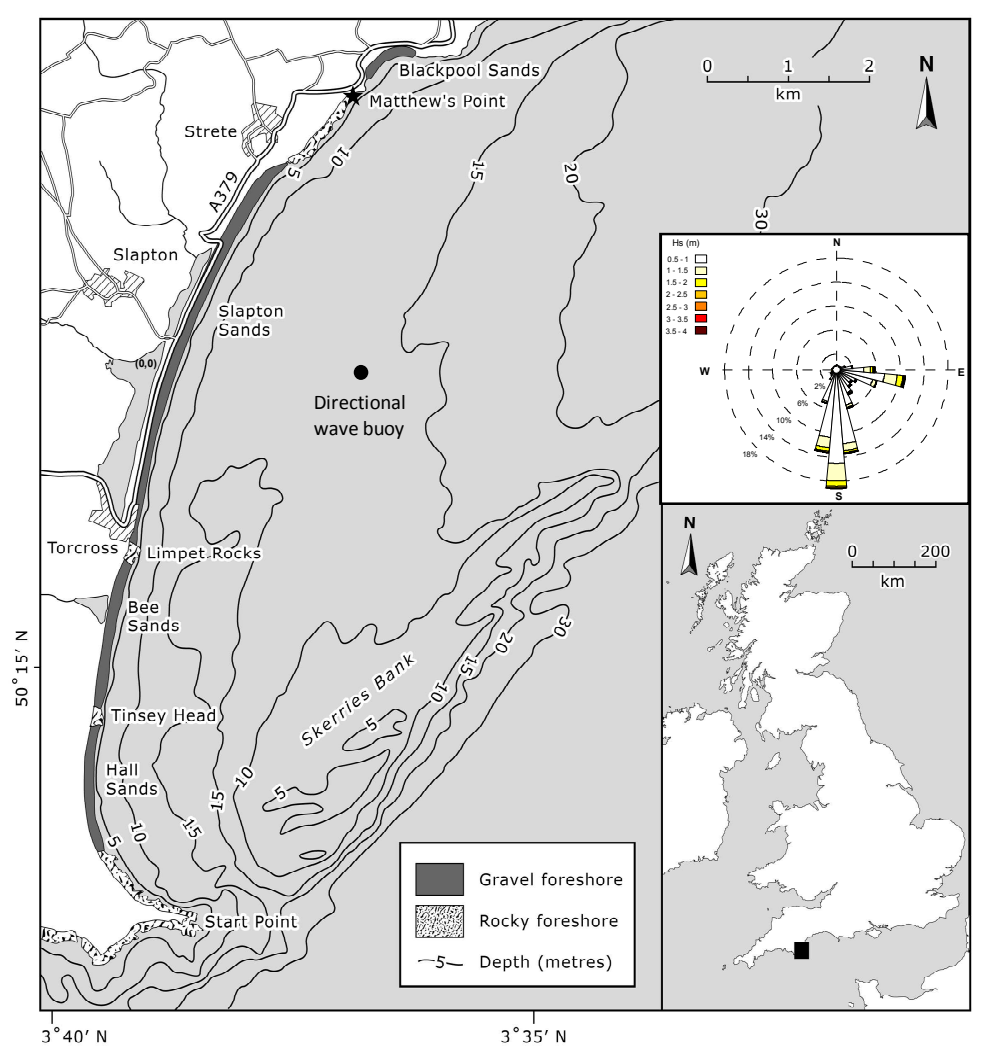

Figure 1. Slapton Sands gravel barrier location within the U.K. The location of the directional wave buoy is indicated by the black dot. The wave field is represented by the wave rose on the top right side. 
The gravel barrier is partly protected from the Atlantic swell propagating up the English Channel by the Start Point headland, and Skerries Bank banner sandy bank (minimum depth of $5 \mathrm{~m} \mathrm{ODN).} \mathrm{The}$ wave climate approaching Slapton Sands is bimodal and dominated by southerly swell waves and easterly wind waves. These waves are characterised by medium energy conditions (mean $\mathrm{H}_{\mathrm{s}} \geq 1 \mathrm{~m}$; storm $\mathrm{H}_{\mathrm{s}} \geq 3 \mathrm{~m}$ ), and the mean spring and neap tide ranges are $4.3 \mathrm{~m}$ and $1.8 \mathrm{~m}$, respectively. Large swash excursions of up to $40 \mathrm{~m}$ have been measured during energetic storms, high spring tides has induced barrier overtopping and overwash events, depositing gravel on the road, and back-barrier. The 1:50 storm surge level in the region is $0.75 \mathrm{~m}$ (Lowe and Gregory 2005), and the current relative sealevel rise is estimated at $2.5 \pm 0.7 \mathrm{~mm}$ per year based on measurements from 1962 to 2004 (Haigh et al. 2009).

On the decadal-to-century time scale there is historical evidence of widening and narrowing of the extreme ends of Start Bay, suggesting the existence of beach rotation possibly induced by changes in the direction of the net littoral drift (Job 1993). This rotation has been documented in the past centuries with the disappearance of two fishing villages located at opposite ends of Start Bay. Recent storms $\left(\mathrm{H}_{\mathrm{s}}\right.$ $\geq 2 \mathrm{~m}$ and minimum duration of 6 hours) have caused severe damage to the supratidal barrier through barrier overwashing. As an example of the extent of the damage caused by these events, a single easterly storm undercut a $250-\mathrm{m}$ section of the road that runs along the top of the barrier crest. In the past years, the barrier has been found to rotate to re-establish its equilibrium in response to the impact of storms from the typical directions (Ruiz de Alegria-Arzaburu and Masselink in press). Moreover, the predominance of one storm type over the other has been found to cause coastal retreat or progression of a few tens of metres (Ruiz de Alegria-Arzaburu et al. 2010).

\section{WAVE MODELLING WITH MIKE21}

In order to investigate the alongshore wave conditions during storms, measured nearshore waves were transformed into shallow water using the MIKE 21 SW flexible mesh spectral wave model (www.dhigroup.com). The nearshore measurements consisted of half-hourly significant wave height, period and peak wave direction recorded by a directional wave buoy (Plymouth Coastal Observatory, www.channelcoast.org) (see Fig. 1).

The model was run with a grid resolution of $10 \mathrm{~m}, 100 \mathrm{~m}$ and $500 \mathrm{~m}$ for the nearshore, Skerries Bank and offshore areas, respectively, and for computational efficiency the parametrically decoupled version of the model (DS module) was used (see Ruiz de Alegria-Arzaburu and Masselink in press for further details). For the simulations, the water level (predicted tides) was varied and wave diffraction was included. A spread factor of 8 and 100 was used based on the directionally decoupled parametric formulation for computing the wind-driven easterly and swell-driven southerly storms, respectively. As the bed sediments below the depth of closure are composed of medium to fine sand (Hails, 1975) a $\mathrm{D}_{50}$ of $0.5 \mathrm{~mm}$ was assumed. A JONSWAP spectrum was used to represent the wave field.

Offshore directional wave data at the model boundary are not available, so the model could not be properly validated and calibrated. Instead, the inshore wave conditions recorded by the directional wave buoy were initially assumed to be representative of the wave conditions at the model boundary and the model was forced using these wave conditions. The difference in wave height and direction between the measured and modelled wave conditions at the buoy position was then used to redefine the wave conditions at the boundary. This was repeated until the difference between measured and modelled wave conditions was minimal.

A southerly $\left(9^{\text {th }}\right.$ of March 2008$)$ and easterly $\left(17^{\text {th }}\right.$ of April 2008) storm were selected to optimise model performance. For the easterly storm this established a need to add a value of $0.43 \mathrm{~m}$ to the boundary $\mathrm{H}_{\mathrm{s}}$ values leaving the wave direction unaltered. For accurate representation of the southerly storm, the boundary $\mathrm{H}_{\mathrm{s}}$ was doubled and $22^{\circ}$ was added to the output wave direction. Results for the easterly storm showed mean errors of $1.8 \%$ and $0.6 \%$ for $\mathrm{H}_{\mathrm{s}}$ and the direction, respectively. For the southerly storm errors of $7.5 \%$ and $11.4 \%$ were obtained for the wave height and direction, respectively (refer to Ruiz de Alegria-Arzaburu and Masselink in press for further details). Model outputs at the buoy location compared with measurements show a good match, and indicate high reliability of the model performance (Fig. 2). 

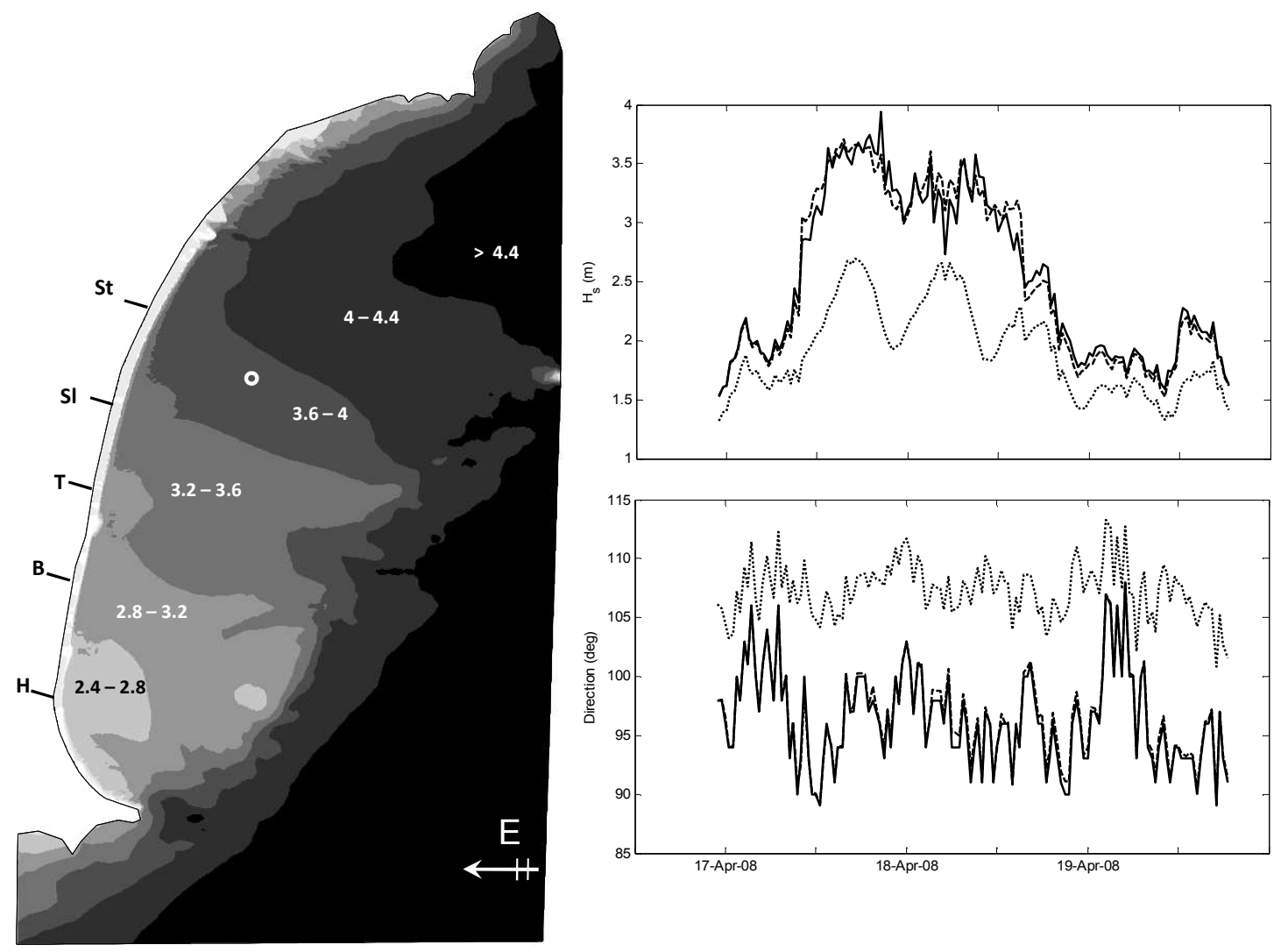

Figure 2. Peak wave heights $(\mathrm{m})$ modeled using Mike 21 for the easterly storm along Start Bay (left panel), and model outputs $\left(\mathrm{H}_{\mathrm{s}}\right.$ and direction) for the wave buoy location (dashed) compared to measured waves (solid line), and modeled inshore waves (dotted) (right panel).

\section{XBEACH MODEL APPLICATION}

\section{Model characteristics}

In the present study the XBeach model developed by Roelvink et al. (2009) has been applied to simulate gravel beach dynamics using the Van Rijn (2007) formulae for sediment transport, and a coupled groundwater module. Short wave (wind and swell) transformations are achieved using a wave action balance (e.g., Holthuijsen et al. 1989), and a roller energy balance is used to parameterise complex wave breaking processes in shallow water (e.g., Stive and Dingemans, 1984). Wave forces accelerate or decelerate the flow described by the nonlinear shallow water equations (NSWE). Based on the wave group varying mass flux associated with the short waves and rollers (e.g., Phillips 1977) the Generalized Lagrangian Mean (GLM) approach (e.g. Walstra et al. 2000) is used to obtain Eulerian flow velocities and allow the inclusion of mass flux contribution to long wave motion and undertow.

Computed hydrodynamic conditions are used to obtain the equilibrium sediment concentration, which acts as a source term for the advection-diffusion equation for sediment (Galapatti 1983). Bedload and suspended load sediment transport rates are computed using the Van Rijn (2007) formulae. Bed level changes are computed from sediment transport gradients and take account of avalanching when slope gradients exceed pre-defined thresholds. The model accounts for feedback between the evolving bathymetry and the hydrodynamics at each time step.

\section{XBeach set-up for Slapton Sands}

The XBeach model was applied to simulate both storm impacts and beach recovery on the Slapton Sands gravel barrier. At Slapton Sands easterly storms are responsible primarily for cross-shore morphological change (Ruiz de Alegria-Arzaburu and Masselink, in press) and are thus the most suitable test cases for the 1D XBeach model. For this reason, the impact of an easterly storm that occurred on the $17^{\text {th }}$ of April 2008, and lasted for 68 hours, was selected for the model simulations. The storm occurred during spring tides and caused significant erosion of the supratidal beach, and some accretion in the intertidal zone. The pre-storm beach profile survey was conducted on the $7^{\text {th }}$ of April during spring tides and immediately after the end of the storm on the $19^{\text {th }}$ of April. As calm conditions 
prevailed between the pre-storm survey and the start of the storm, the profile measured on the $7^{\text {th }}$ of April is considered to match closely the profile just prior to the storm. This assumption reduced significantly the computational time, and permitted simulation of the entire storm period of 68 hours.

Calm periods were found to be dominated by onshore sediment transport, resulting in the construction of a berm on the upper intertidal/lower supratidal zone (Ruiz de Alegria-Arzaburu and Masselink, in press). Here, the model performance is assessed on its ability to reproduce berm formation. In these simulations, beach profiles measured before and after a calm period on the $19^{\text {th }}$ of April and the $5^{\text {th }}$ of May 2008 were selected. The post-storm beach profile measured on the $19^{\text {th }}$ of April defined the starting profile in these simulations. Model outputs were then compared with the profile measured on the $5^{\text {th }}$ of May, which is considered a representative of a typical beach profile after approximately three days of calm conditions.

Being one of the narrowest sections of the barrier, and very vulnerable to erosion, a cross-shore profile located in the middle of the barrier (see Fig. 1) was selected for the model simulations. The measured beach profiles were interpolated on a regular grid with a 1-m horizontal and vertical resolution. The model boundary was defined as $-5 \mathrm{~m}$ ODN, and to accommodate the incident wave field, the measured low tide (c. $-2 \mathrm{~m})$ was linearly extrapolated up to the offshore model boundary $(-5 \mathrm{~m}$ ODN). This resulted in the addition to the measured profile an interpolated horizontal segment of length of $35 \mathrm{~m}$ (Fig. 3). This extrapolated subtidal zone is not considered when assessing volumetric sediment balances between the eroded and accreted zones on the measured sections of the beach profile. In order to be able to compute barrier overwash events, the barrier profile was extended to the back-barrier lagoon (Fig. 3). The initial barrier profile used in the model simulations is shown in Figure 3 , and represents measured beach profiles for the storm and calm conditions, and the lagoon water table (LWT) in relation to the location of the subtidal, intertidal and supratidal zones.

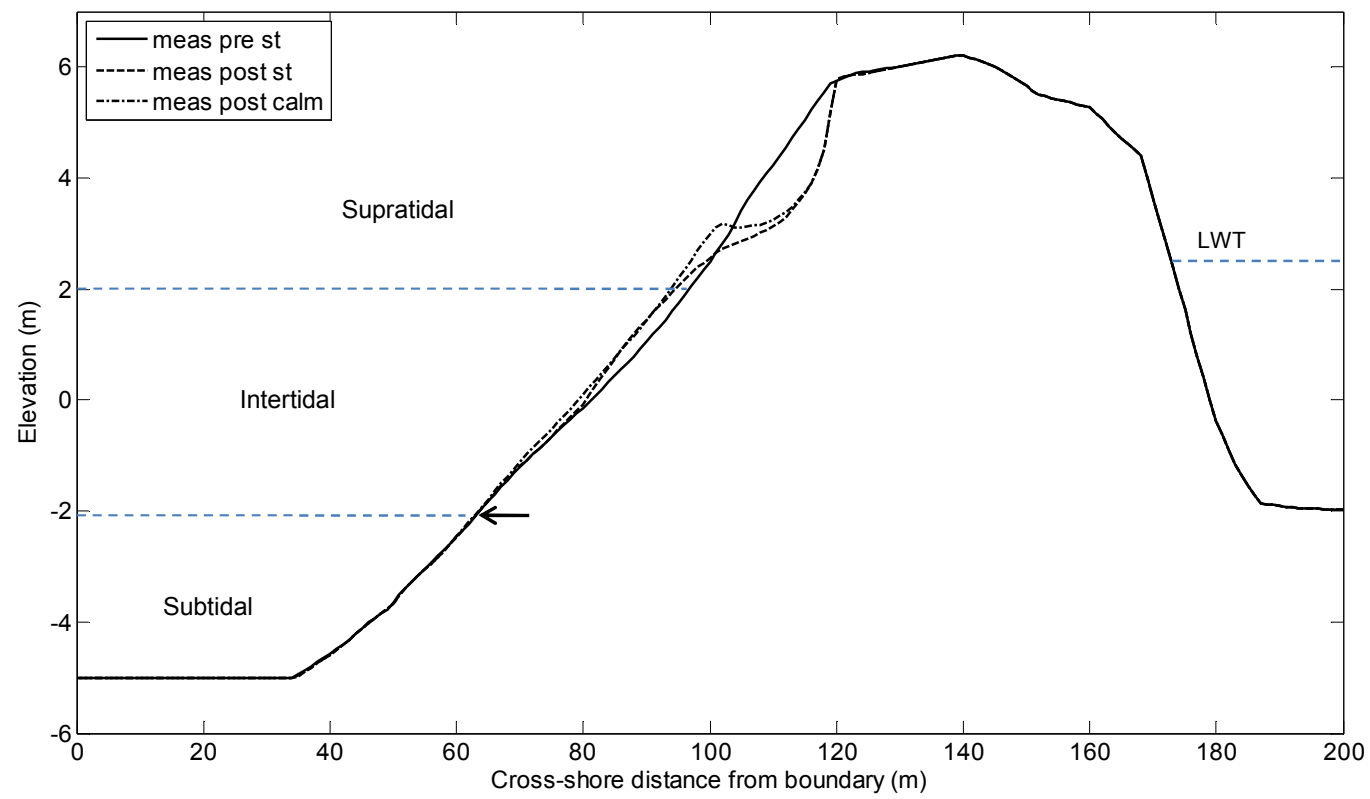

Figure 3. Cross-sectional view of the gravel barrier from the sea (left) towards the lagoon side (right). The lagoon water table (LWT) and the subtidal, intertidal and supratidal beach zones are indicated. The measured beach profiles before and after the storm, and after the calm period are presented as full, dashed and dashdotted lines, respectively. The arrow represents the typical depth up to which field survey data were collected.

XBeach was used in non-stationary mode and inshore JONSWAP wave spectra at $-5 \mathrm{~m}$ ODN were defined by MIKE 21 output (see Fig. 2). Due to the lack of locally measured tides, XBeach was run in combination with modelled predicted tides with added tidal residuals measured in Weymouth (British Oceanographic Data Centre) (Fig. 4). During the simulated storm, the tidal levels ranged between -1.4 $\mathrm{m}$ and $2 \mathrm{~m} \mathrm{ODN}$.

The lagoon water elevation in the model was fixed at 2.5m ODN (Austin et al. 2009, Fig. 3). The groundwater seepage driven by the resulting hydraulic gradient between the ocean and back-barrier lagoon was included in the XBeach simulations. The initial groundwater table through the beach was defined using linear interpolation between the fixed lagoon water level and the tidal level at each time 
step. In XBeach, the sediment was characterised by: $\mathrm{D}_{50}=6 \mathrm{~mm} ; \mathrm{D}_{90}=9 \mathrm{~mm}$; sediment density $=2500$ $\mathrm{Kgm}^{-3}$; porosity $=0.4$; and bed roughness, $\mathrm{z}_{0}-0.006$ ( Soulsby-Van Rijn, 1997). All simulations were performed using a morphological factor (fmorf) of 1 (see Roelvink et al. 2009 for further details).

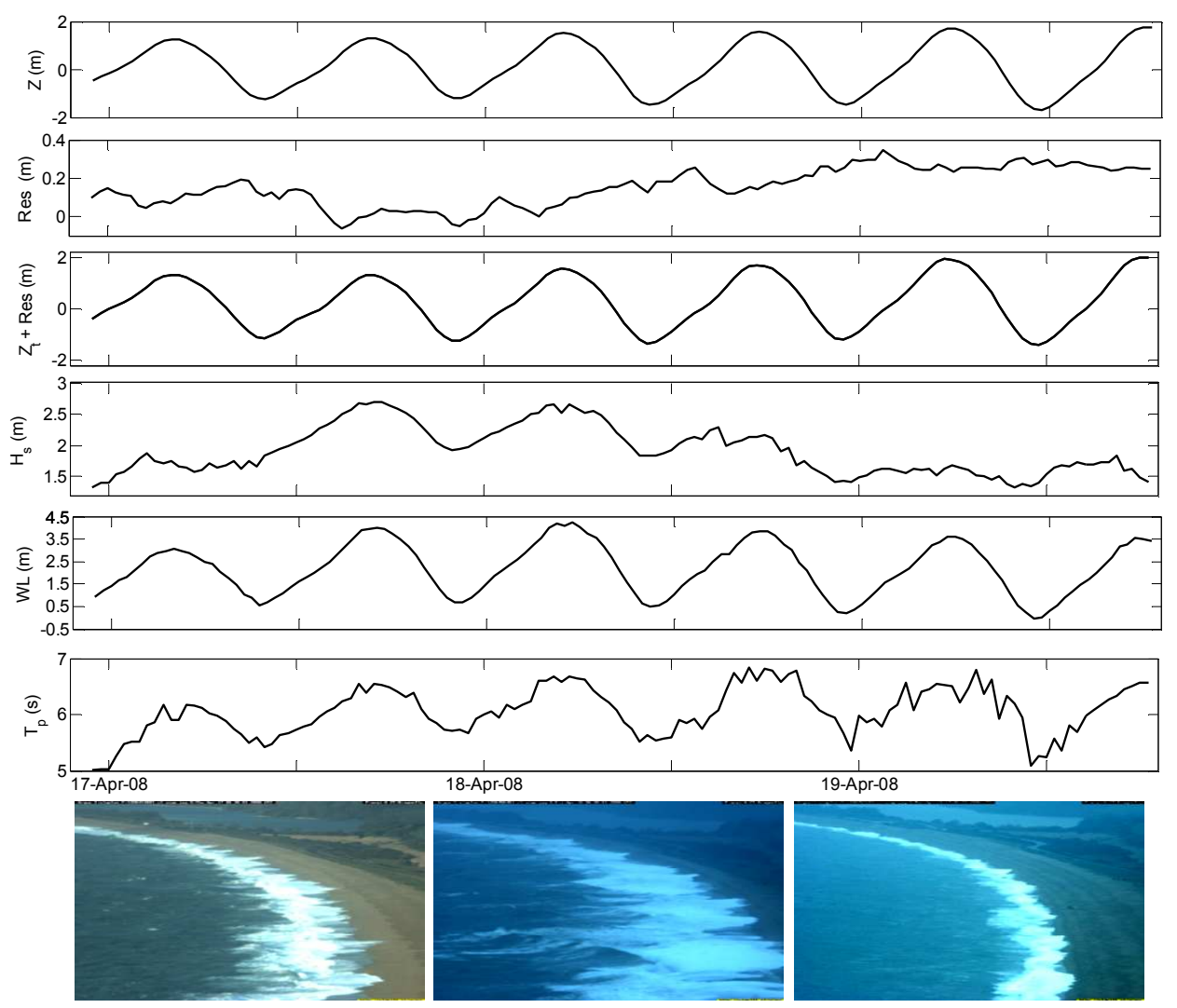

Figure 4. Predicted tides at Slapton ( $m, O D N)$, tidal residuals from Weymouth (m, ODN), predicted tides with residuals, and inshore wave heights and wave periods at $5 \mathrm{~m}$ depth (from top to bottom) applied to the storm model simulations. Argus images taken before, during and after the modeled easterly storm (left to right) are shown in the bottom.

\section{BRIER SKILL SCORE}

The Brier Skill Score (BSS) gives an objective assessment on the capability of a model to provide accurate predictions (Eq. 1), and it has been widely used to assess the skill of coastal morphological models (e.g., Pedrozo-Acuña et al. 2006).

$$
B S S=1-\left[\frac{\left\langle x_{p}-\left.x_{m}\right|^{2}\right\rangle}{\left\langle\left|x_{b}-x_{m}\right|^{2}\right\rangle}\right]
$$

where $x_{b}$ is the initial beach profile (baseline), $x_{m}$ is the measured beach profile, and $x_{p}$ the predicted profile by the model. Perfect agreement gives a skill score of 1 , and negative values indicate that predictions are worse than the baseline value.

BSS compares the mean square difference between the prediction and observation with the mean square difference between baseline prediction and observation. Thus, it measures the accuracy of a prediction relative to the accuracy of a baseline prediction (Sutherland et al. 2004). Here, the BSS statistical descriptor will be applied to measure the skill of XBeach to predict the profile at the end of the model simulations. Interpretation of values from BSS were provided by Van Rijn et al. (2003), and indicated bad model performance for values $>0$, poor for values $>0.3$ reasonable/fair for $0.3-0.6$, good for 0.6-0.8, and excellent over 0.8 . 


\section{RESULTS}

The following Section presents results of a series of tests that will examine:

- Sensitivity analysis. Model performance to different values of friction coefficient and hydraulic conductivity will be studied in order to define an optimum model set-up. Model performance will be assessed with the BSS statistical descriptor (i.e. described below).

- The capability of XBeach to reproduce post-storm beach response and beach recovery. For the storm simulation, the model is set-up with the measured pre-storm beach profile; the corresponding hydrodynamic conditions for the storm are imposed at the boundary, and the post-storm model output is compared with the measured post-storm profile. The same approach is taken to study the model performance during calm conditions using the measured post-storm profile as an initial model profile, and the model output will be compared with the measured profile after the calm period.

-Define a threshold for barrier overwash. The sensitivity of the barrier to overwash is studied imposing additional water levels to a large spring tide and in combination with the largest waves measured over the monitoring period.

\section{Sensitivity analysis}

XBeach requires the input of several parameters to perform the simulations. Most of the parameters are associated with physical processes and some reference values are available in the literature. Recommended settings for sandy beaches have been used for the set-up of the hydrodynamics. On gravel beaches, however, most of the parameters related to morphology are unknown, thus, initially their values are assumed, and a sensitivity analysis is performed to check their validity. In particular, two parameters have the most influence on model predictions: the drag coefficient $\mathrm{C}_{\mathrm{D}}$ ( $c f$ in XBeach) and the hydraulic conductivity $\mathrm{K}$.

Model performance to different $C_{D}$ values was carried out using a hydraulic conductivity $K$ value of $0.05 \mathrm{~ms}^{-1}$ suggested by Austin et al. (2009) for Slapton Sands. Studies on sandy beaches generally use a $C_{D}$ value of 0.002 (Soulsby 1997). Here, values between 0.002 and 0.02 were tested in order to cover an estimated range of sand to coarse gravel. Figure 5 shows that the morphological variability along the beach profile is sensitive to $C_{D}$. A first qualitative assessment of the model performance to different values of $\mathrm{C}_{\mathrm{D}}$ suggests a best value of 0.007. A quantitative assessment through the Brier Skill Score BBS calculation (Eq. 1) for the profile section covered by measured data (above $-1.5 \mathrm{~m}$ ) indicates best agreement for $\mathrm{C}_{\mathrm{D}}$ of 0.007 and 0.01 (Fig. 5). Both values provide reasonable/fair predictions, and $\mathrm{C}_{\mathrm{D}}$ of 0.007 was considered the most appropriate as showing highest BSS and best agreement with the cut-back across the supratidal beach. These findings agree well with the range of $C_{D}$ values used by Pedrozo-Acuna (2005) for modelling gravel beach response.

The hydraulic conductivity $\mathrm{K}$ is a relevant factor which determines cross-barrier seepage of water and, hence, the amount of sediment transport and morphological variability (e.g., Austin et al. 2009). Initially, a $\mathrm{K}$ value of $0.05 \mathrm{~ms}^{-1}$ was used. The performance of XBeach using $\mathrm{K}$ values from $0.01 \mathrm{~ms}^{-1}$ (suggested for $\mathrm{D}_{50}=1-2 \mathrm{~mm}$; Masselink and Li (2001)) and up to $0.15 \mathrm{~ms}^{-1}$ (measured for $\mathrm{D}_{50}=10 \mathrm{~mm}$ during a large-scale laboratory gravel barrier dynamics experiment, BARDEX, Williams et al. (2009)) was examined to determine the suitability of the value suggested by Austin et al. (2009). The same range of values was suggested by Barnes (1995) for gravel beaches. Model results showed that the beach response to wave forcing is sensitive to $\mathrm{K}$ and that for low values of $\mathrm{K}$ (e.g., $0.01 \mathrm{~ms}^{-1}$ ) the upper beach erosion and lower beach accretion were overestimated. An increase in $\mathrm{K}$ by an order of magnitude (from 0.01 to $0.1 \mathrm{~ms}^{-1}$ ) caused the opposite effect and underestimated the upper beach erosion. Best beach morphology predictions were obtained using a $\mathrm{K}$ value of $0.05 \mathrm{~ms}^{-1}$, which also provided highest BSS results (Fig. 5). This is in agreement with the K-estimate of Austin and Masselink (2005) based on field measurements undertaken at Slapton Sands. 

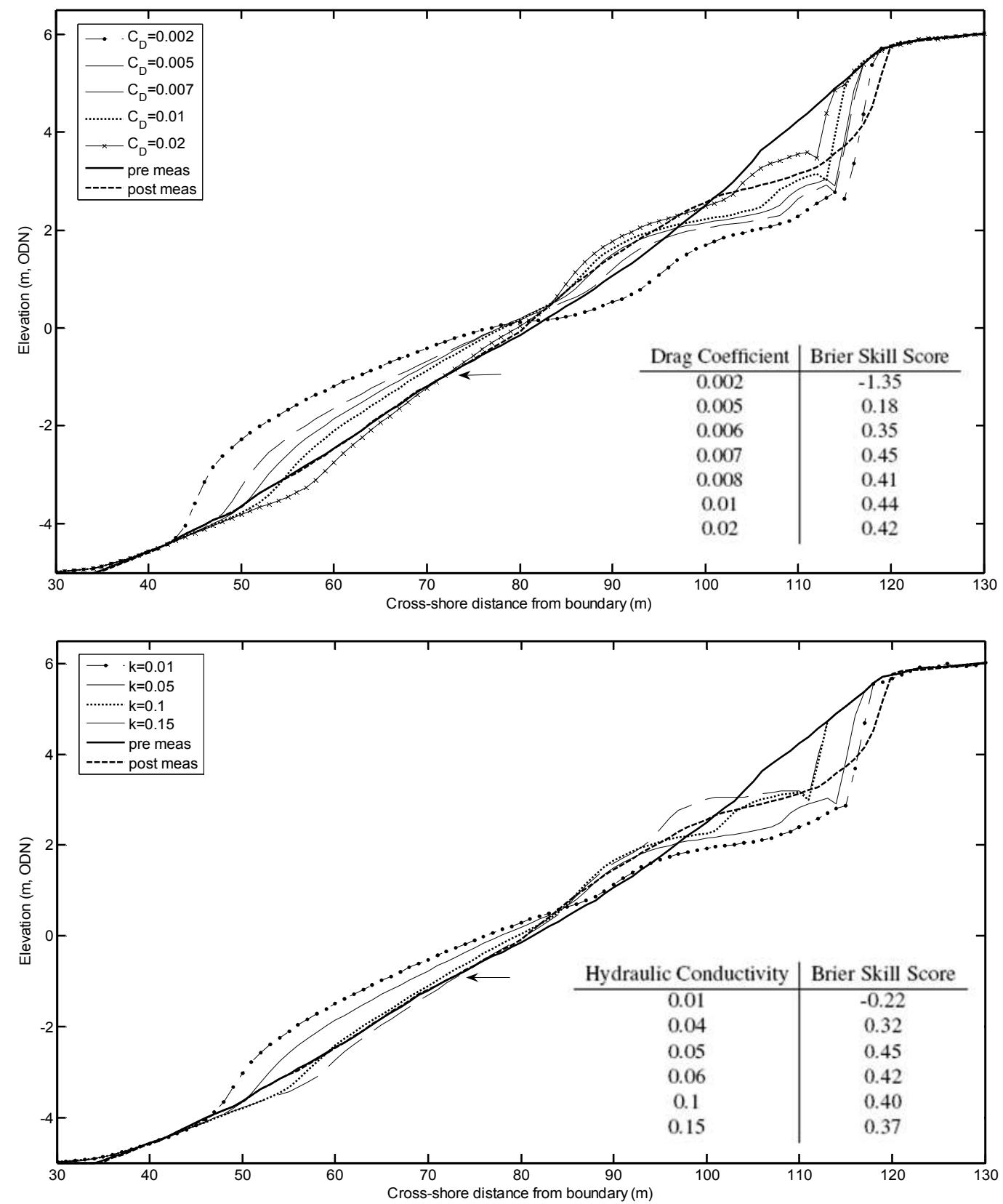

Figure 5. XBeach model simulation outputs for varying $C_{D}$ in comparison to the measured pre- and poststorm beach profiles (thick lines), and using a $\mathrm{K}$ of $0.05 \mathrm{~m} \mathrm{~s}^{-1}$ (top panel), and varying $\mathrm{K}$ and using $\mathrm{C}_{\mathrm{D}}$ of 0.007 (bottom panel). The arrow indicates the limit for the field measured profiles, thus, for the Brier Skill Score calculations.

\section{Post-storm beach response and beach recovery}

The $17^{\text {th }}$ of April 2008 storm was modelled using the optimised parameters derived using the sensitivity analysis described above (i.e. $\mathrm{K}=0.05 \mathrm{~m} \mathrm{~s}^{-1}$ and $\mathrm{C}_{\mathrm{D}}=0.007$ ). Model results are presented in Figure 6 and show that XBeach is capable of reproducing well the measured profile after the storm. Model outputs are inconsistent with field measurements across the middle intertidal beach (0 to $-1.5 \mathrm{~m}$ ODN). It is considered that this may be attributable to beach profile changes brought about by longshore sediment transport. The Brier Skill Score (BSS) was calculated to assess the accuracy of XBeach to predict the post-storm profile covered by measured data (above $-1.5 \mathrm{~m}$ ), and a value of 0.45 was obtained, which implies a reasonable/fair prediction. As outlined above, due to the lack of field data across the lower intertidal and subtidal profile, it was not possible to compare the model output with measurements for the lower region of the beach (Fig. 3). 


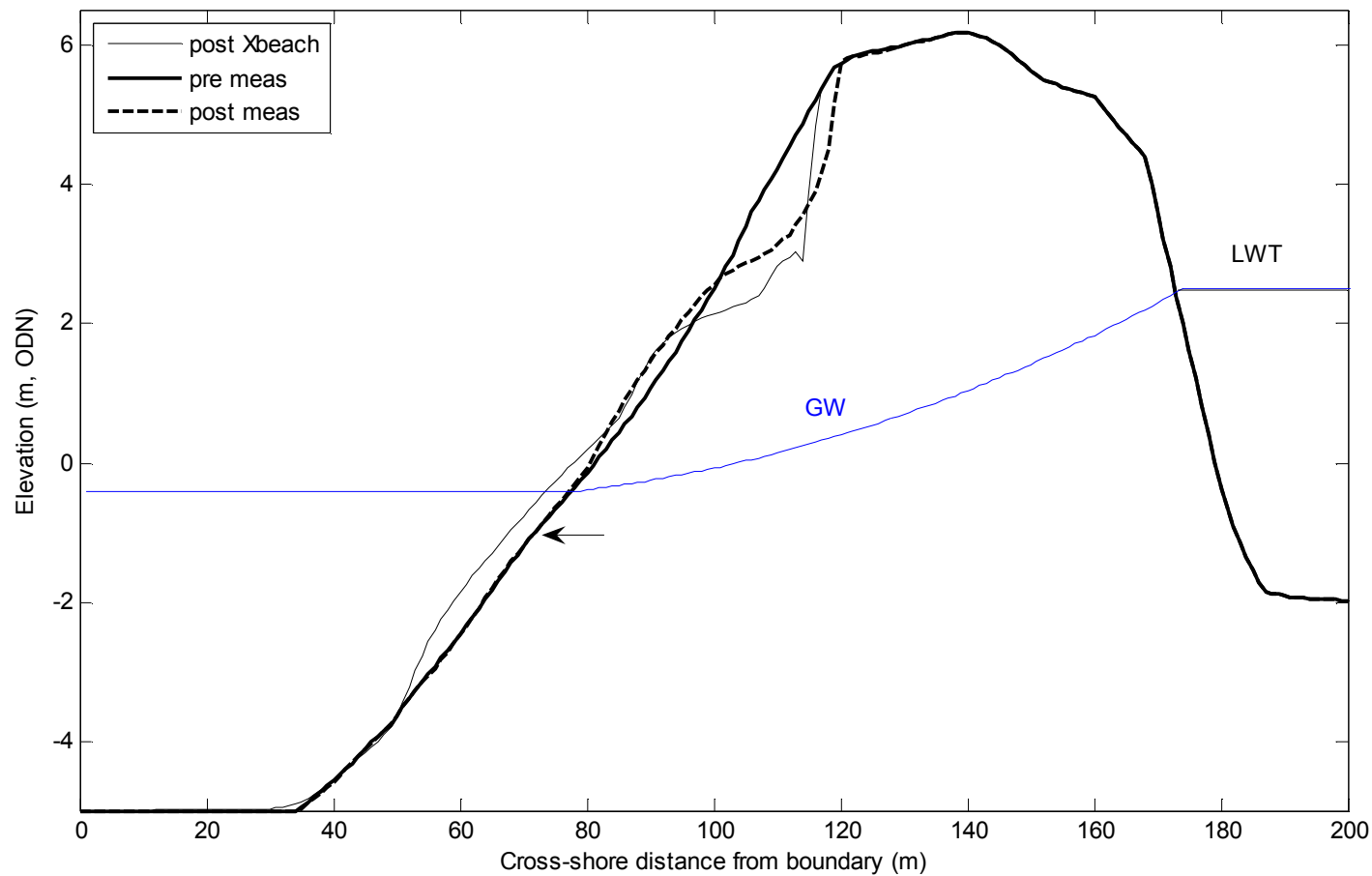

Figure 6. Post-storm XBeach output (thin solid line) compared to the measured pre- and post-storm profiles (thick full and dashed lines). The groundwater table (GW) for the initial model run, and the lagoon water table (LWT) are also represented. The arrow indicates the limit for field measurements.

In calm wave conditions dominant net onshore sediment transport leads to beach accretion. XBeach was run to predict beach recovery recorded after the $19^{\text {th }}$ of April 2008 storm. Field measurements showed that during the calm period gravel was carried upslope as far as the swash zone extended, and deposited in the form of a berm. Model results indicated that XBeach is unable to simulate beach accretion in the form of a constructive berm on the upper intertidal beach. Instead, it caused some erosion across the upper intertidal zone and deposition of the eroded gravel across the lower intertidal beach (Fig. 7). Thus, at present, the model is not able to simulate post-storm beach recovery on a gravel beach.

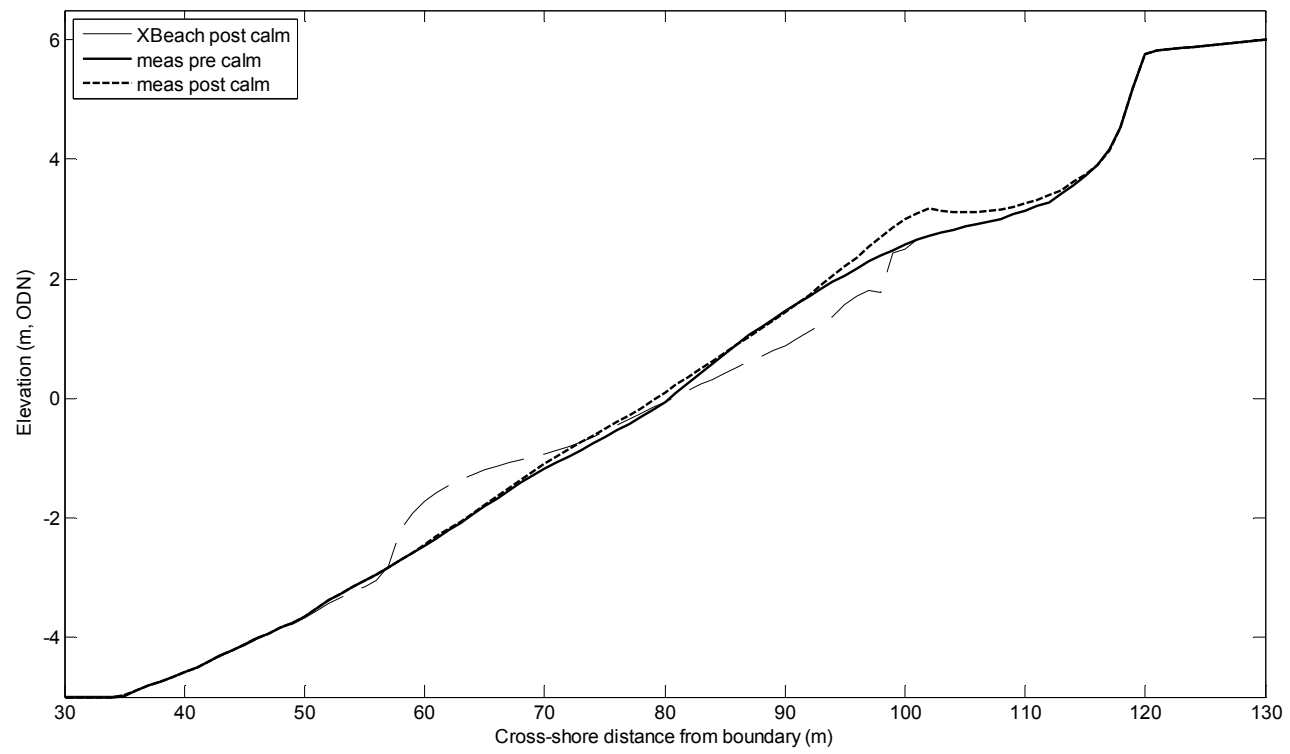

Figure 7. XBeach output after calm wave conditions (fine dashed line) versus measured beach profiles before and after the calm period (full and thick dashed lines), and using a $C_{D}$ of 0.007 and a $\mathrm{K}$ of $0.05 \mathrm{~m} \mathrm{~s}^{-1}$. 


\section{Barrier overwash threshold}

The average measured surge elevation at Weymouth during the modelled storm was $0.15 \mathrm{~m}$ (Fig. 4). During the modelled storm, however, there is evidence to suggest that the surge at Slapton Sands was higher than $0.15 \mathrm{~m}$, and a surge of $0.3 \mathrm{~m}$ could be considered a reasonable value. In order to test the morphological response of the barrier to increased surges, a set of model simulations have been carried out adding extra water levels of $0.2,0.3$ and $0.4 \mathrm{~m}$ to the already accounted predicted tides and measured surge from Weymouth. A BSS of 0.66 was obtained for an added water level of $0.3 \mathrm{~m}$ (Fig. 8 ), thus, showing that XBeach is capable of providing good predictions using a realistic surge value for the modelled storm. The modelled supratidal and upper intertidal morphology show close qualitative and quantitative agreement with measurements (Fig. 8). The middle intertidal beach (0 to $-1.5 \mathrm{~m}$ ODN), however, shows poor agreement with measurements, and this can be attributed to longshore sediment transport.

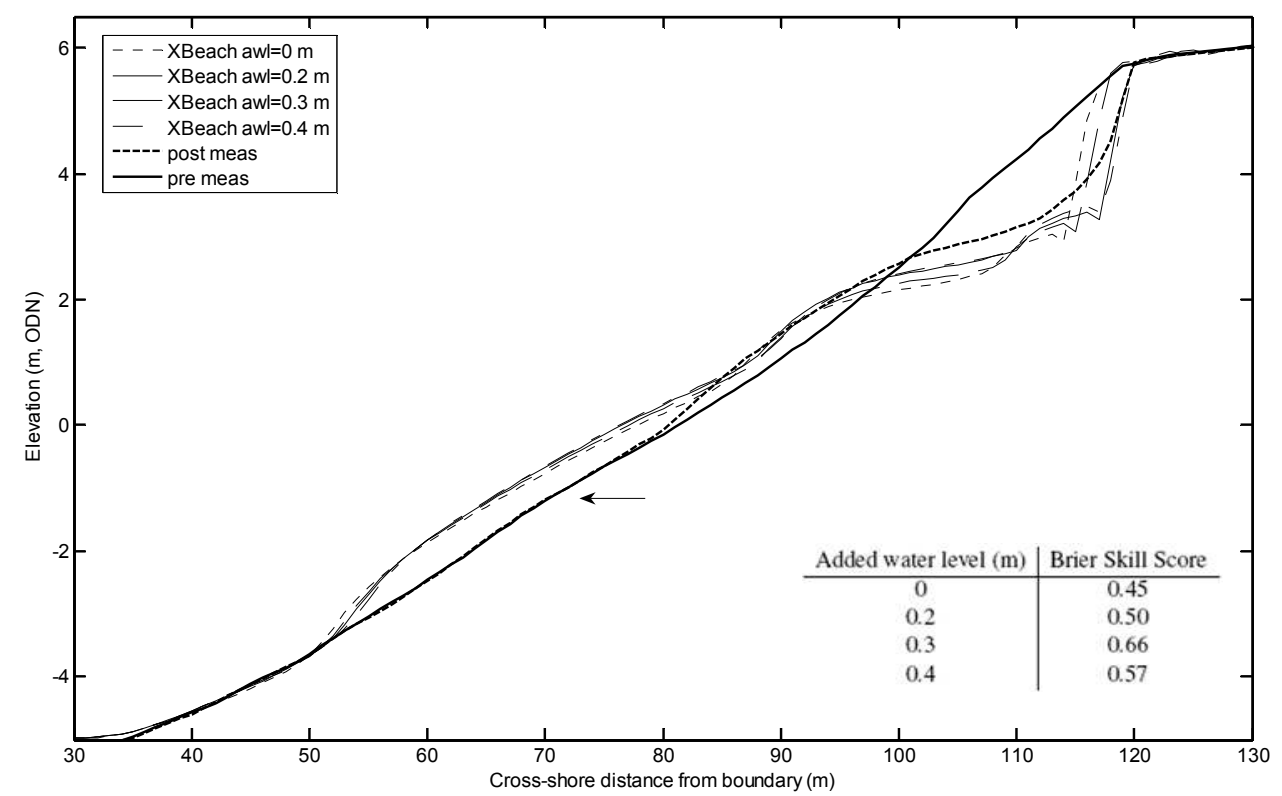

Figure 8. XBeach results for added water levels (awl) of $0,0.2,0.3$ and $0.4 \mathrm{~m}$, and compared to the measured pre- and post-storm beach profiles (thick full and dashed lines, respectively). The arrow indicates the limit for field measurements.

The above results indicate that XBeach is capable of accurately reproducing storm-induced supratidal barrier erosion. Gravel barriers are very sensitive to overwash events, and in recent years, storm-induced barrier overwash has caused significant erosion across the barrier crest at Slapton Sands. Thus, it is desirable to have a model capable of providing accurate predictions for overwash induced morphological change.

Storm surge values of damaging overwash events at Slapton Sands are inexistent, but it is known that the 50-year return period storm surge level along Start Bay is c. $0.75 \mathrm{~m}$ (Lowe and Gregory, 2005). Here, a set of model simulations have been carried out to forecast scenarios with increased extreme water levels. Future extreme barrier overwash occurrence has been studied over a measured large spring tide (tidal range $4.5 \mathrm{~m}$ ), adding water levels of 1, 1.4, 1.6, 2, 2.2 and $2.4 \mathrm{~m}$ to the model tides (predicted and Weymouth surge), and using the largest recorded easterly storm waves (Figs. 9 and 10).

In order to study the influence of the prevailing profile morphology on the occurrence of barrier overwash, the same set of model simulations have been carried out using both the pre- and post-storm profiles as initial model conditions. Model results indicate that the barrier crest starts to erode with an added water level of $1.6 \mathrm{~m}$ when the beach profile is already eroded (Fig. 9), and with an added water level of $1.8 \mathrm{~m}$ for simulations with a pre-storm profile (Fig. 10). The road is located a few meters onshore from the barrier crest (refer to Study Site for details), thus, damage to the road will only take place when barrier overwash occurs. The threshold for barrier overwash was found with an added water level of $2 \mathrm{~m}$ for both simulations. 

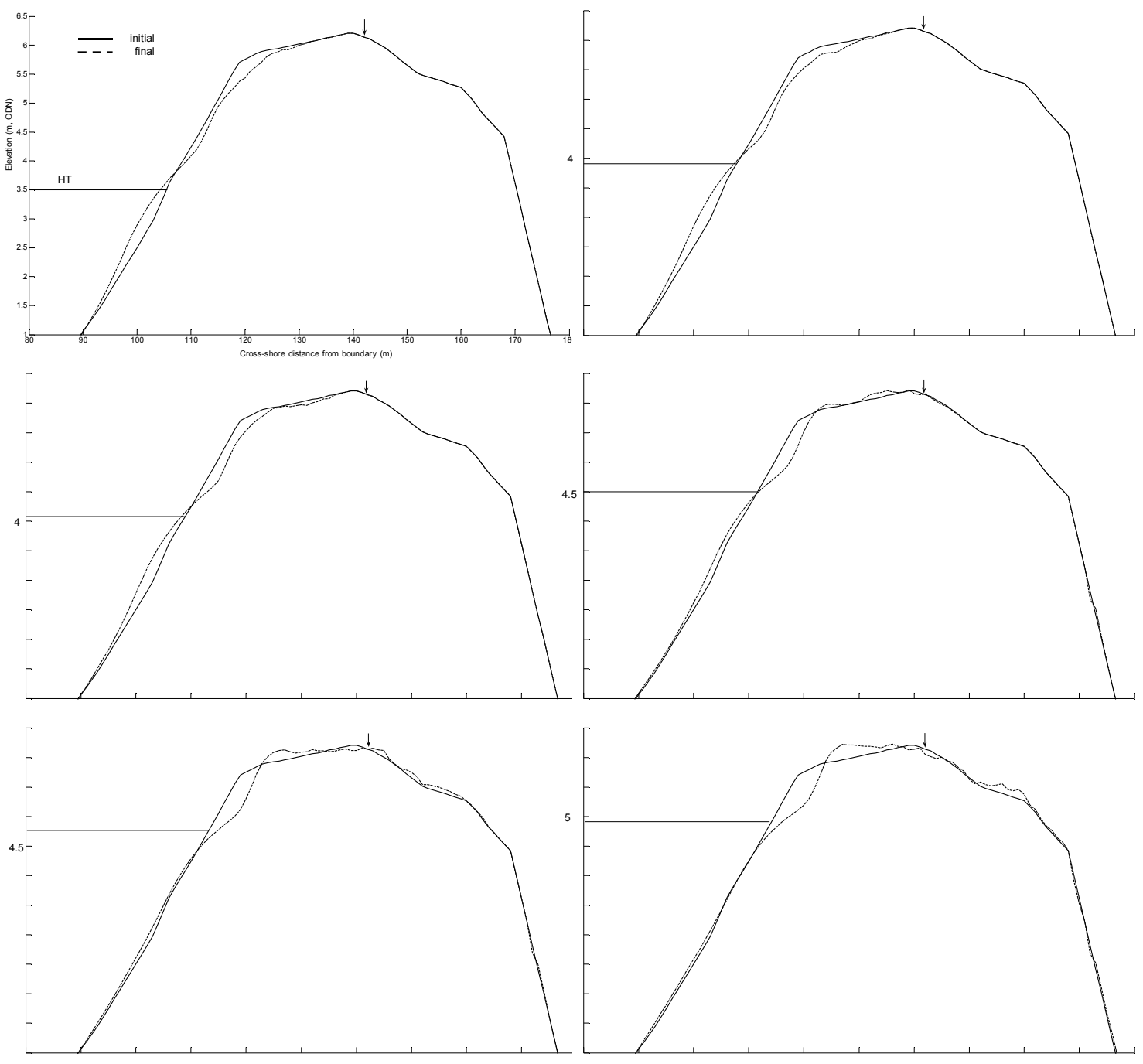

Figure 9. Overwash model results using the pre-storm profile as an initial profile for the XBeach simulations, and adding water levels of 1, 1.4, 1.6, 2, 2.2 and $2.4 \mathrm{~m}$ from top left to bottom right, respectively. The high tide (HT) level $(m, O D N)$ is represented by the horizontal line, and the road location is pointed by an arrow. 

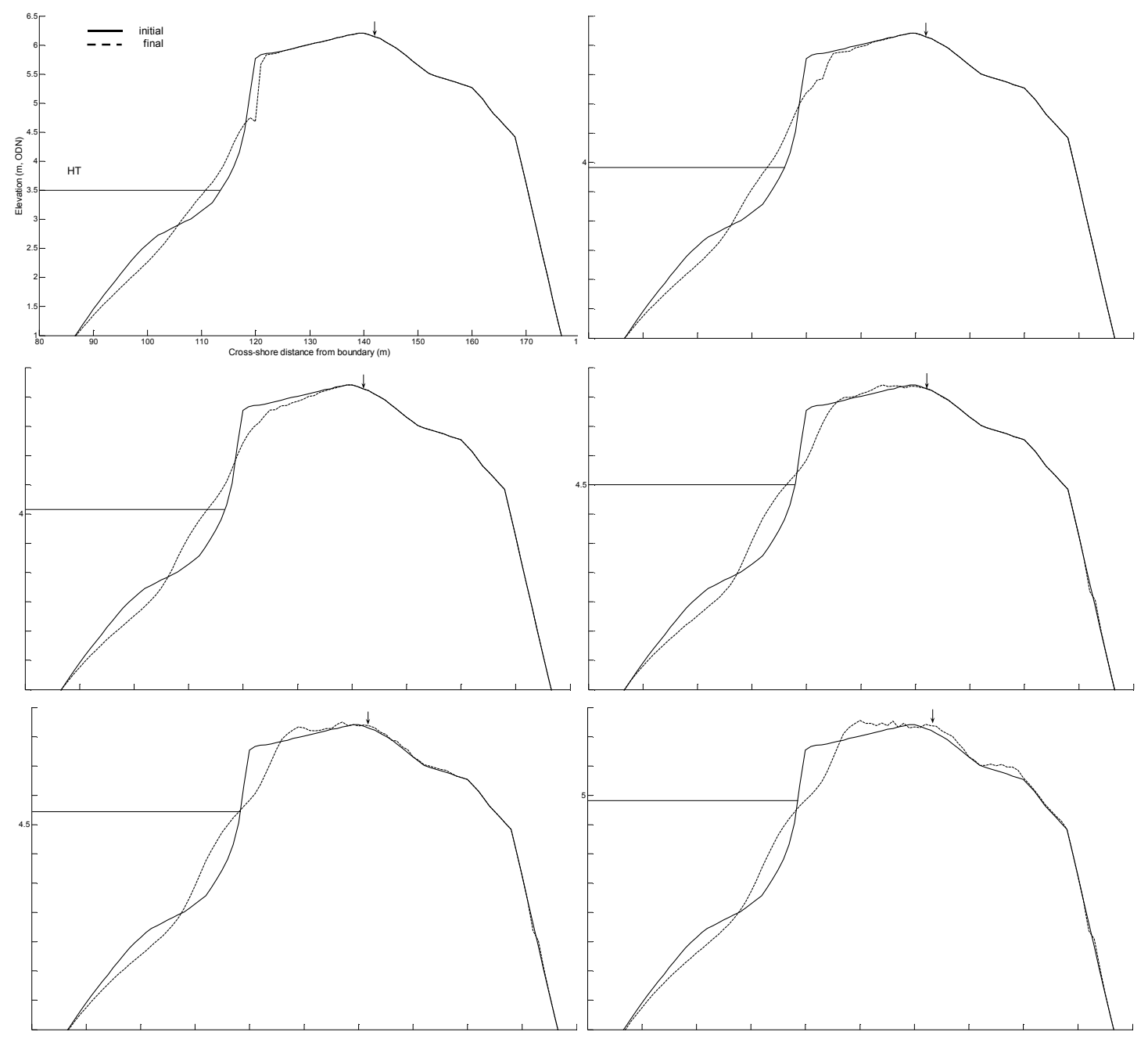

Figure 10. Overwash model results using the post-storm profile as an initial profile for the XBeach simulations, and adding water levels of $1 \mathrm{~m}, 1.4 \mathrm{~m}, 1.6 \mathrm{~m}, 2 \mathrm{~m}, 2.2 \mathrm{~m}$ and $2.4 \mathrm{~m}$ from top left to bottom right, respectively. The high tide (HT) level ( $m, O D N)$ is represented by the horizontal line, and the road location is pointed by an arrow.

\section{CONCLUSIONS}

Gravel beach dynamics during storm and calm conditions were examined at Slapton Sands through the application of the XBeach 2DH numerical model. Morphological gravel beach response was found to be very sensitive to the beach permeability and drag coefficient, both of which exert significant control on sediment mobility. Best morphological results were obtained for $\mathrm{K}=0.05 \mathrm{~m} \mathrm{~s}^{-1}$ in agreement with the K-estimate of Austin and Masselink (2005), and for $C_{D}=0.007$, which agrees well with the range of $C_{D}$ values used by Pedrozo-Acuña (2005) for modelling gravel beach response.

Model results indicated that an overestimation of the hydraulic conductivity $\mathrm{K}$ by c. $30 \%$ underpredicts the supratidal volume by c. $15 \%$, while an underestimation of K by c. $20 \%$ overpredicts the volume by c. $8 \%$. This indicates that the hydraulic conductivity controls the amount of swash infiltration through the barrier, and the resulting beach morphological response, as previously found by Masselink and Li (2001) and Austin and Masselink (2005). The morphological response of the gravel beach was found very sensitive to the drag coefficient $C_{D}$, which determines the shear-stress and the corresponding sediment mobility. The underestimation of $C_{D}$ by c. $30 \%$ causes significantly larger supratidal and upper intertidal erosion, and lower intertidal and subtidal accretion, while its overestimation induces the opposite response. 
XBeach is capable of reproducing successfully storm-induced supratidal erosion and upper intertidal accretion, driven by a net offshore flow. The model skills were tested with the calculation of the Brier Skill Score (BSS) statistical descriptor. Initially, XBeach provided reasonable/fair predictions, with a BSS value of 0.45 , using predicted tides and tidal residuals from Weymouth. An increase in the water level by $0.3 \mathrm{~m}$ led to good model capability, with a BSS of 0.66 . The improvement in model performance with the added water level of $0.3 \mathrm{~m}$ could be partly attributed to the underestimation of the storm surge level, and possibly, mainly, to the inability of XBeach to model individual swashes and properly predict the runup limit. Overall, both model predictions simulate the supratidal and upper intertidal morphology adequately. The middle intertidal beach, however, shows poor agreement with measurements, and this is attributed to the longshore sediment transport, as the neighbouring areas to the modelled profile showed significant accretion across the middle intertidal beach.

The berm formation is driven by a net onshore flow (Austin and Masselink 2005; Masselink et al. 2010) the gravel is carried upslope from offshore/subtidal zone and is deposited onto the upper runup limit (upper intertidal zone). XBeach is unable to reproduce beach recovery conditions through the construction of a berm. On the contrary, a berm feature is reproduced during the barrier overtopping simulations. For the vertical accretion of the berm, the berm crest is required to be overtopped (Takada and Sunamura 1982; Austin and Masselink 2005), and during the overwash runs the overtopping is enhanced through the increase in the water level. Thus, the inability of the model to reproduce berm formation is mainly attributed to the fact that XBeach models long group waves rather than individual waves, which eliminates the relevant sediment transport effect of the individual swashes capable of reaching the berm crest, and accreting it. In addition, the inability of the model to produce onshore transport could be also attributed to the fact that the sediment transport model is $\mathrm{u}^{3}$-driven and cannot drive sediment onshore.

During the model simulations, the morphological condition of the beach prior to the storm was found to be a relevant factor which determines the location and amount of morphological change across the beach profile. The occurrence of barrier overwash was studied with XBeach simulating large spring tides (i.e., $4.5 \mathrm{~m}$ ), and combined with large wave heights during high tide (i.e., $\mathrm{H}_{\mathrm{s}}>2.6 \mathrm{~m}$ ). The barrier crest was found to erode with an added water level of $1.6 \mathrm{~m}$ when the initial profile was depleted (after a storm), and $1.8 \mathrm{~m}$ for an accretive initial profile. The threshold for barrier overwash was found with an added water level of $2 \mathrm{~m}$ for both simulations. It is unlikely to have such a large added water level. A fraction of this level could be attributed to the storm surge, and other fractions could correspond to larger waves (and of longer period), and also to the limitation of XBeach to reproduce swash hydrodynamics.

At Slapton Sands, the road is located a few meters onshore from the barrier crest, and damage to the road will take place with barrier overwash. This will be expected under conditions of an easterly storm characterised by large waves (i.e., $\mathrm{H}_{\mathrm{s}}>2.6 \mathrm{~m}$ ), and during a high spring tide, with an estimated storm surge of c. $0.75 \mathrm{~m}$ (as the recorded at Devonport during the January 2001 storm; British Oceanographic Data Centre), and with a depleted beach prior to the storm. This study presents the first application of a numerical model to study gravel beach/barrier dynamics at time scales of hours-todays. Despite the existing limitations, XBeach is found useful to simulate storm-induced morphological change and barrier overwash thresholds across a gravel beach/barrier.

\section{ACKNOWLEDGMENTS}

Amaia Ruiz de Alegria-Arzaburu gratefully acknowledges the support given by the School of Geography at the University of Plymouth through a departmental $\mathrm{PhD}$ scholarship. The authors are very thankful for the guidance on the use of XBeach provided by the leading group from Deltares and TUDelft.

\section{REFERENCES}

Austin, M. and Masselink, G. 2005. Infiltration and exfiltration on a steep gravel beach: implications for sediment transport, Coastal Dynamics, ASCE p. 13.

Austin, M., Masselink, G., Turner, I., Buscombe, D. and Williams, J. 2009. Groundwater seepage between a gravel barrier beach and a freshwater lagoon, International Conference on Coastal Engineering 2008, pp. 4572-4584.

Barnes, G. 1995. Soil mechanics principles and practice, Macmillan Press Ltd. ISBN 0-333-59654-4. 
Bradbury, A. 2000. Predicting breaching of shingle barrier beaches-recent advances to aid beach management, Proceedings of $35^{\text {th }}$ Annual MAFF Conference of River and Coastal Engineers, 05.3.1-05.3.13.

Bradbury, A. and Powell, K. 1992. The short term profile response of shingle spits to storm wave action, Proceedings of the International Conference on Coastal Engineering, ASCE, 2694-2707.

Brampton, A. and Motyka, J. 1994. Modelling the plan shape of shingle beaches, Lecture Notes in Coastal Engineering Studies, 12 Offshore and Coastal Modelling' 85 pp. 219-234.

Chadwick, A. J. 1989. Field measurements and numerical model verification of coastal shingle transport, BHRA, The Fluid Engineering Centre, Cranfield, Bedford 27.

Chadwick, A. J., Karunarathna, H., Gehrels, W. R., O’Brien, D. and Dales, D. 2005. A new analysis of the Slapton barrier beach system, UK', Proceedings of the Institution of Civil Engineers-Maritime Engineering 158(4), 147-161.

Clarke, S. and Damgaard, J. 2002. Applications of a numerical model of swash zone flow on gravel beaches, Proceedings of $28^{\text {th }}$ International Conference on Coastal Engineering.

Galapatti, R. 1983. A depth-integrated model for suspended transports, Report 83- 7. Faculty of Civil Engineering, Delft University of Technology. Delft. The Netherlands.

Haigh, I., Nicholls, R. and Wells, N. 2009. Mean sea level trends around the English Channel over the 20th century and their wider context, Continental Shelf Research 29(17), 2083-2098.

Hails, J. R. 1975. Offshore morphology and sediment distribution, Start Bay, Devon, Philosophical Transactions of the Royal Society of London Series -Mathematical Physical and Engineering Sciences 279(1288), 221-228.

Holthuijsen, L. H., Booij, N. and Herbers, T. H. C. 1989. A prediction model for stationary, shortcrested waves in shallow water with ambient currents, Coastal Engineering 13(1), 23-54.

Job, D. 1993. The Start Bay barrier beach system, FSC occasional publication 27 of a field guide of the geomorphology of the Slapton region. Field Studies Council (Slapton Ley Field Studies Centre). U.K.

Lindemer, C.A., Plant, N.G., Puleo, J.A., Thompson, D.M., Wamsley, T.V. 2010. Numerical simulations of a low-lying barrier island's morphological response to Hurricane Katrina. Coastal Engineering 57, 985-995.

Lopez de San Roman-Blanco, B., Coates, T. T., Holmes, P., Chadwick, A. J., Bradbury, A., Baldock, T. E., Pedrozo-Acuna, A., Lawrence, J. and Grune, J. 2006. Large scale experiments on gravel and mixed beaches: Experimental procedure, data documentation and initial results, Coastal Engineering 53(4), 349-362.

Lowe, J. A. and Gregory, J. M. 2005. The effects of climate change on storm surges around the United Kingdom, Philosophical Transactions of the Royal Society a Mathematical Physical and Engineering Sciences 363(1831), 1313-1328.

Mason, T. and Coates, T. T. 2001. Sediment transport processes on mixed beaches: A review for shoreline management, Journal of Coastal Research 17(3), 645-657.

Masselink, G. and Li, L. 2001. The role of swash infiltration in determining the beachface gradient: a numerical study', Marine Geology 176, 139-156.

Masselink, G., Russell, P., Blenkinsopp, C. and Turner, I. 2010. Swash zone sediment transport, step dynamics and morphological response on a gravel beach, Marine Geology 274, 50-68.

McCall, R., Van Thiel de Vries, J., Plant, N., Van Dongeren, A., Roelvink, J. A., Thompson, D. and Reniers, A. 2010. Two-dimensional time dependent hurricane overwash and erosion modelling at Santa Rosa island, Coastal Engineering 57, 668-683.

Nicholls, R. and Wright, L. 1991. Longshore transport of pebbles: experimental estimates of K., Proceedings of Coastal Sediments'91, ASCE. 1, 920-933.

Obhrai, C., Powell, K. and Bradbury, A. 2008. A laboratory study of overtopping and breaching of shingle barrier beaches, 31st International Conference on Coastal Engineering, ASCE, 1497-1508

Pedrozo-Acuña, A. 2005. Concerning swash on steep beaches, PhD Thesis, University of Plymouth, Unpublished pp. 225 pp.

Pedrozo-Acuña, A., Simmonds, D. J., Otta, A. K. and Chadwick, A. J. 2006. On the cross-shore profile change of gravel beaches, Coastal Engineering 53(4), 335-347.

Phillips, O. 1977. The dynamics of the upper ocean, Cambridge Univ. Press, New York p. 336.

Powell, K. 1990. Predicting short term profile response for shingle beaches, HR Wallingford SR report 219. 
Pye, K. and Blott, S. J. 2009. Progressive breakdown of a gravel-dominated coastal barrier, DunwichWalberswick, Suffolk, UK: Processes and implications, Journal of Coastal Research 25(3), 589602 .

Riddell, K. J. and Young, S. W. 1992. The management and creation of beaches for coastal defense, Journal of the Institution of Water and Environmental Management 6(5), 588-597.

Roelvink, D., Reniers, A., van Dongeren, A., de Vries, J. V., McCall, R. and Lescinski, J. 2009. Modelling storm impacts on beaches, dunes and barrier islands, Coastal Engineering 56(11-12), $1133-1152$.

Ruiz de Alegria-Arzaburu, A., Pedrozo-Acuna, A., Horrillo-Caraballo, J., Masselink, G. and Reeve, D. E. 2010. Determination of wave-shoreline dynamics on a macrotidal gravel beach using Canonical Correlation Analysis, Coastal Engineering 57, 290-303.

Ruiz de Alegria-Arzaburu, A. and Masselink, G. 2010. Storm response and beach rotation on a gravel beach, Slapton Sands, U.K., Marine Geology, in press.

Soulsby, R. 1997. Dynamics of marine sands, HR Wallingford, Ed. Thomas Telford p. 261.

Soulsby, R. L. and Damgaard, J. S. 2005. Bedload sediment transport in coastal waters, Coastal Engineering 52(8), 673-689.

Stive, M. J. F. and Dingemans, M. 1984. Calibration and verification of a one dimensional wave energy decay model. Report on investigation, Delft Hydraulics, Delft, The Netherlands.

Sutherland, J., Peet, A. H. and Soulsby, R. L. 2004. Evaluating the performance of morphological models, Coastal Engineering 51(8-9), 917-939.

Takada, I. and Sunamura, T. 1982. Formation and height of berms, Transactions Japanese Geomorphological Union 3, 145-157.

Van Dongeren, A., Benavente, J., Balouin, Y., Ciavola, P., Taborda, R., Furmanczyk, K., Haerens, P., Roelvink, D., Trifonova, E. and Williams, J. 2009. Micore: Dune erosion and overwash model validation with data from nine European field sites, Proceedings of $6^{\text {th }}$ International Conference on Coastal Dynamics 2009, 166-167.

Van der Meer, J. 1988. Rock slopes and gravel beaches under wave attack, Delft Hydraulics Publications 396.

Van Rijn, L. C., Walstra, D. J. R., Grasmeijer, B., Sutherland, J., Pan, S. and Sierra, J. P. 2003. The predictability of cross-shore bed evolution of sandy beaches at the time scale of storms and seasons using process-based profile models, Coastal Engineering 47(3), 295-327.

Van Rijn, L. C. 2007. Unified view of sediment transport by currents and waves: Initiation of motion, bed roughness, and bed-load transport, Journal of Hydraulic Engineering, 133(6), 649-667.

Van Wellen, E., Chadwick, A. J. and Mason, T. 2000. A review and assessment of longshore sediment transport equations for coarse-grained beaches, Coastal Engineering 40(3), 243-275.

Walstra, D., Roelvink, J. A. and Groeneweg, J. 2000. Calculation of wave-driven currents in a 3D mean flow model, $27^{\text {th }}$ International Conference on Coastal Engineering, pp. 1050-1063.

Williams, J., Masselink, G., Buscombe, D., Turner, I., Matias, A., Ferreira, O., Bradbury, A., Metje, N., Coates, L., Chapman, D., Thompson, C., Albers, T. and Pan, S. 2009. BARDEX (Barrier Dynamics Experiment): Taking the beach into the laboratory, Journal of Coastal Research 1, 158162. 10th International Coastal Symposium, ICS 2009, Lisbon, Portugal, Sp. Iss. 56. 